\title{
The Teaching of Ataturk as a Historical Hero in the Social Studies Lesson: A Study on Social Studies Teacher Candidates*
}

\author{
Ali Altıkulaç \\ Çukurova University, Faculty of Education, Balcal1, Adana, Turkey
}

\begin{abstract}
In recent years, the removal of the ideological issues from the textbooks and contents has come into question. Many researchers have made works and comments about the place and status of Ataturk in the syllabus. Particularly, the ideals such as decontamination from the militarism, staying away from a dominant doctrine, peaceful education approach, avoidance of blind patriotism, gaining global perspective stand out in the critiques towards Social Studies and T.R. (Turkish Republic) Revolution History and Kemalism (Ataturkism). This study aims to demonstrate the basic views of the candidate teachers as the selected study group, on the granting of place to Ataturk as a historical hero in Social Studies Lesson. In the study, total of 141 teachers were defined as a working group studying the social studies teacher section. This basic research design will be used as descriptive model in the study. In light of results of study, social studies teacher candidates' perceptions about Ataturk were high and according to them, Mustafa Kemal Ataturk can be taught as a historical hero because of various reasons.
\end{abstract}

Keywords: Social studies, teacher candidate, hero, Ataturk

\section{Introduction}

From the past to the present, at the History and Social Studies lessons the most commonly used way for the value teaching is to use historical heroes. The roles of heroes for distinguishing the good and bad and lives of these heroes, their struggle for what, so what importance they give etc. facts have made conducive to use heroes in the value teaching. Heroes male or female are not only glorious and celebrated, but also the ones who revealed the moral standards and values of the society they live with their behaviors. Some heroes are universalized beyond their own society with values they did and they had. Each country gives place to the national heroes in their teaching programs. It has been given place to historical characters in teaching programs such as Nelson Mandela (South Africa), Mahatma Gandhi (India), Abraham Lincoln (USA), Fidel Castro (Cuba), Charles de Gaulle (France) and so on. Turkish History is full of national heroes who can serve as role models to children; one of the most prominent of these is, of course, Mustafa Kemal Ataturk. The goal of teaching the philosophy of Ataturk's revolutions to the next generation manifests itself almost every size of Turkish education system.

The period of implementation of the Social Studies teaching to students is between 12-14 years of age. Adolescence period is psychological identification made for this time. Adolescence is a time involving rebellion and identity confusion described as a period of stress and tension. Considering the period of adolescence as a search for identity, it is the time period that adolescents choose their role as a model with the possible identity of the hero figures in the community (Balswick, 1982). By its most general definition, «hero» is one who confronts a serious problem that challenge people's ideas and goals, with the difficulty or conflict and overcomes the problem as a result of his or her individual actions using features such as power, courage or nobility. As well as for heroines, devotion, morality, kindness and fortitude are features which are more accepted (Brodbelt \& Wall, 1985). According to Staats, Hupp \& Hagley (2008), honesty is the most significant component of heroism; because honesty minimizes ability to reject or neutralize unwanted sides in a person's behavior shown while moving and heroic actions. Hero is the form of our ideals that have already taken shape, the opponent of our hidden needs, the image of our own dreams; analyzing hero is equivalent to analyze ourselves (Warren, 1972). Challenging and life-saving heroes in the films, music stars with impressive displays and of course, as well as political systems tend to create their own mythological heroes.

Throughout the history of mankind, heroes have been identified as models of behavior for themselves. Heroes varies based on the components such as time, place, culture, beliefs and so on. Historical conditions and special situations usually allow the emergence of a hero.

Approach to benefit from hero in education reflects the understanding of idealistic and realistic philosophy of education, fundamentally. In the whole world as in Turkey, although there is the directivity from teacher-centered approach towards a student-centered approach and from idealist and realist philosophy to pragmatic philosophy in education; this change does not reduce the importance of the role of teachers in education and values education (Yazıcı \& Aslan, 2011).

According to Turkish Presidency of General Staff (1982), "Ataturkism (Kemalism)" is considered to be the principles

* This study has been supported under the project 2016-5698 SBA-coded by Çukurova University Scientific Research Projects Coordination Unit. This article was presented at International Journal of Arts \& Sciences' (IJAS) International Conference for Education held in Barcelona, Spain, May 23-26, 2016. 


\section{International Journal of Science and Research (IJSR) \\ ISSN (Online): 2319-7064}

Index Copernicus Value (2013): 6.14 | Impact Factor (2015): 6.391

and ideas which stated by Ataturk on the purpose of leading the Turkish culture above the modern civilizations by the guidance of science and logic. Kemalism aims to provide a state that's sovereignty belongs to the nation, it also aims for total independence, peace and welfare for Turkish nation for today and tomorrows. Principles of Ataturk are known as "Kemalism" in the western world. For the Turkish Nation, these principles are inspired by Mustafa Kemal's surname, Ataturk, and is known and accepted to be as "Ataturkism" (Erendil, 1986:9) Aslan,(1991) claims Kemalism to be an unique World-view that consist of republicanism, populism, secularism, revolutionism, nationalism, statism, rationalism, being scientific and contemporary, total independence and anti-imperialism and passivism. Kemalism, generally identified as a system which involves any way that seeks to reach and unite the idea of modern civilization. The philosophical core aims to teach how to think rather than what to think (Sağlam, 1988). According to İsmet Giritli, Kemalism is an ideology of modernization based on pragmatism. Kemalism foresees and aims to provide democracy, modernity and total independency for eternity for Turkish Republic which is an unitary nation state. The perpetuity of state requires continuous reforms that will keep nation at peace and unity and will follow the idea of modern civilization (Giritli, 1995).

There are differences about education of "Kemalism" between the old curriculum of social studies and the new one which has been followed since 2005. The subjects of Kemalism are given through different courses as a whole entity not separated. Kemalism is associated with social studies; its subjects are applied to the syllabus considering the background of students (Yazic1 \& Koca, 2008). From the 4th grade to the 7th, the subjects of Ataturk's life, characteristics, and his contributions to the World, Turkish Nation, Turkish history and culture, Ataturk's view on science, his principles and reforms are given integrated within the syllabus. Besides the Social Studies, Kemalism is also applied on courses such as Turkish, Mathematics, Science and Technology. The aim is to reach the ideas of Kemalism and perceive its goals.

Kemalism subjects would be bordered if it was kept within the History teaching and analyzing only the historical facts and events chronologically. It should be considered within a wider perspective; Kemalism should be thought as a system of principles which aims to prepare the students to the contemporary-modern world. It is a system which forms the social conditions and which regulates the daily life issues (Oğuz et al., 2005). The subjects about Kemalism should be examined from a scientific approach and the curriculums should be re-organized. To make Kemalism more fruitful, the curriculum should benefit from different methods and strategies such as going to the historical places and museums, practicing creative drama courses, watching documentaries with students, regulating symposiums, conferences, panels and brainstorming. Also there could be poetry, composition, drawing contests and projects which deal with Ataturk's ideas and opinions in past, present and future times (Koca, 2005).

There could be two reasons behind why the social studies include Kemalism in their curriculum. The first reason is social studies' one of the main object is to teach Kemalism. In other words, it could be defined as a legal obligation. The second reason is social studies' deal with such subjects like Kemalism, it is in the nature of social studies. (Yazic1, 2009). In recent years, there are issues considering the removal of ideological subjects from the curriculums. People who call themselves as Kemalist and who do not, who works in social sciences' field have made comments on the place and status of Kemalism in the syllabuses. Especially in the criticisms raised against Social Studies and Turkish Republic Reform History Course claims that these courses should be cleansed from militarism, an oppressive doctrine, blind nationalism and should be replaced with a peaceful education method and global world-view. These are the ideals of the criticisms that draw attention. For mentioned criticism's method seeks to give an objective general perspective on the lives of political leaders lived in the past and put them into the curriculum. Mustafa Kemal Ataturk has unique characteristics which differentiate him from the other leaders. Besides his countless characteristics that could be perfect examples for children, he is the founder of Turkish Republic and this is enough to take place in education process of Turkey. What should be done here is not to subtract or decrease the number of subjects about Ataturk from curriculums but to make students be able to know the most important figure that Turkish culture brought and students should see him as a person who could be taken as a role model.

\section{Method}

The research technique is descriptive survey model. Since this research tries to analyze the perspectives of the social studies' teacher candidates' views on teaching Ataturk as a historical hero, the descriptive survey model is used. Survey model is the proper way of examining, since it aims for describing things as they are (Karasar, 1999). Research's working group consists of 141 teacher-candidates who are already receiving their education in a state university, in department of Social Studies education. The data of research collected in fall semester of 2015-2016. The feedback forms that are prepared by researchers and "Perception of Ataturk Scale" developed by Donmez and Hamarat (2014) have been used in collecting the data of research. Through feedback forms which contain 1 open-end question, the data was collected in written forms: "Should we teach Ataturk in social studies as a historical hero? Why?" The taken answers have been categorized in charts regarding their percentage and frequencies. While analyzing the data, it has been observed that some students preferred to give more than one answers. As a result of this, the number of working group which is indicated by (n) and the frequency of numbers in categories which is indicated by (f) show different results. To enhance the reliability of analysis of the data, percentage values are given besides the frequency numbers. Survey data were analyzed by another academician except for the researcher. In determining the reliability of research, the reliability formula was referred that revealed by Miles and Huberman (1994). Accordingly, the question asked in the survey was calculated as $89 \%$. If the calculated value is .70 and above is considered a reliable indicator of the results of the study. Perception of Ataturk Scale consists of 32 matter, and in the form of 5 point Likert scale. The matters in the 


\section{International Journal of Science and Research (IJSR) ISSN (Online): 2319-7064 \\ Index Copernicus Value (2013): 6.14 | Impact Factor (2015): 6.391}

scale's total matter correlation change between .51 and .77 values. Also the matters in the scale's matter factor load change between .43 and .81 values. The scale's intended internal consistency is known to be Cronbach Alpha index .94. All these values show the reliability of the scale and also the results associated with the scale show how efficient the scale is to evaluate the Ataturk perception (Donmez \& Hamarat, 2014).

\section{Findings}

Points based on items were analyzed of Ataturk Perception Scale applied to teachers working group, descriptive statistics were revealed. Also t-test results according to gender has been presented in tables and participants' views and reasons about teaching of Ataturk as a historical hero in Social Studies lesson.

Table 1: Study Group's Mean Scores of Ataturk Perception Scale

\begin{tabular}{|c|c|c|c|}
\hline Items & $N$ & $X$ & $S$ \\
\hline $\begin{array}{l}\text { Item } 1 . \text { I listen carefully to what told about } \\
\text { Ataturk. }\end{array}$ & 141 & 4,25 & ,95 \\
\hline Item 2. & 141 & 3,77 & 1,31 \\
\hline Item 3. & 141 & 3,91 & 1,16 \\
\hline $\begin{array}{l}\text { Item 4. I am aware of my responsibilities } \\
\text { pointed out by Ataturk. }\end{array}$ & 141 & 3,95 & 1,10 \\
\hline Item 5. & 141 & 3,92 & ,95 \\
\hline Item 6. & 141 & 3,76 & 1,13 \\
\hline $\begin{array}{l}\text { Item 7. When mention of National Struggle } \\
\text { Period, it comes to my mind as the first name } \\
\text { of Ataturk. }\end{array}$ & 141 & 4,14 & 1,05 \\
\hline $\begin{array}{l}\text { Item 8. Ataturk is an ideal model for } \\
\text { students. }\end{array}$ & 141 & 4,15 & 1,09 \\
\hline Item 9. & 141 & 3,65 & 1,17 \\
\hline Item 10. & 141 & 3,50 & 1,06 \\
\hline Item 11. & 141 & 3,54 & 1,35 \\
\hline $\begin{array}{l}\text { Item } 12 . \text { Even in a noisy environment, I can } \\
\text { distinguish the sound of Ataturk. }\end{array}$ & 141 & 3,41 & 1,37 \\
\hline Item 13 & 141 & 3,69 & 1,18 \\
\hline Item 14. & 141 & 3,63 & 1,26 \\
\hline Item 15. & 141 & 3,42 & 1,40 \\
\hline $\begin{array}{l}\text { Item 16. Ataturk is nothing more than a } \\
\text { historical fact for me. }\end{array}$ & 141 & 2,86 & 1,50 \\
\hline Item 17. & 141 & 3,46 & 1,17 \\
\hline Item 18. & 141 & 3,93 & 1,04 \\
\hline Item 19. & 141 & 3,69 & 1,13 \\
\hline $\begin{array}{l}\text { Item 20. Ataturk has a significant influence } \\
\text { in shaping my life philosophy. }\end{array}$ & 141 & 3,29 & 1,34 \\
\hline Item 21. & 141 & 3,60 & 1,15 \\
\hline Item 22. & 141 & 3,87 & 1,02 \\
\hline Item 23. & 141 & 3,92 & 1,22 \\
\hline Item 24. & 141 & 3,90 & 1,21 \\
\hline Item 25. & 141 & 3,89 & 1,16 \\
\hline $\begin{array}{l}\text { Item 26. Kemalist thought system is a } \\
\text { universal character. }\end{array}$ & 141 & 4,07 & 1,04 \\
\hline Item 27. & 141 & 4,01 & 1,07 \\
\hline Item 28. & 141 & 3,90 & 1,19 \\
\hline $\begin{array}{l}\text { Item 29. Overload information on Ataturk } \\
\text { cools me of related issues. }\end{array}$ & 141 & 2,90 & 1,30 \\
\hline $\begin{array}{l}\text { Item 30. I can defend Ataturk's ideas in any } \\
\text { environment. }\end{array}$ & 141 & 3,19 & 1,23 \\
\hline Item 31. & 141 & 3,85 & 1,04 \\
\hline Item 32. & 141 & 3,88 & 1,18 \\
\hline
\end{tabular}

As shown in Table 1, arithmetic means and standard deviations of answers that the teachers candidates have answered to items in Ataturk Perception Scale, are given. In table, it is given to the content of items which has the highest and lowest scores. According to this table, the items with the highest means are "I listen carefully to what told about Ataturk.", "Ataturk is an ideal model for students.", "When mention of National Struggle Period, it comes to my mind as the first name of Ataturk." and the items with lowest means are "Ataturk is nothing more than a historical fact for me.", "Overload information on Ataturk cools me of related issues.", "I can defend Ataturk's ideas in any environment.". Looking at items, it can be said that participants have high perception levels about Ataturk in general.

Table 2: t-Test results for gender difference of study group's test points about Ataturk perception

\begin{tabular}{|c|c|c|c|c|c|c|}
\hline \multirow{2}{*}{ Total } & Gender & $\mathrm{N}$ & $\mathrm{X}$ & $\mathrm{S}$ & $\mathrm{t}$ & $\mathrm{p}$ \\
\cline { 2 - 6 } & Male & 68 & 3,71 &, 89 & 0,75 & 0,94 \\
\cline { 2 - 5 } \cline { 3 - 4 } & Female & 73 & 3,72 &, 77 & & \\
\hline
\end{tabular}

According to Table 2, it was observed that there was not statistically significant difference according to gender about the perception of Ataturk $\left(t_{(141)}=0.75 ; p<0.05\right)$. Looking at the arithmetic average scores, it was observed that the difference was not in favor of female or male. This finding could be interpreted as Ataturk' perception of both gender were in the positive direction close to each other.

Table 3: Social Studies teacher candidates' views and reasons about teaching of Ataturk as a historical hero in Social Studies lesson

\begin{tabular}{|c|c|c|c|c|c|}
\hline Decision & $\begin{array}{l}\mathrm{n} \\
\%\end{array}$ & Reasons & $\begin{array}{c}\mathrm{f} \\
(\%)\end{array}$ & Reasons & $\begin{array}{c}\mathrm{F} \\
(\%)\end{array}$ \\
\hline \multirow[t]{8}{*}{ Yes } & \multirow[t]{8}{*}{$\begin{array}{r}126 \\
89.4\end{array}$} & $\begin{array}{c}\text { As a sample } \\
\text { (model) personality } \\
\text { for pupils. }\end{array}$ & $\begin{array}{c}25 \\
13.1\end{array}$ & $\begin{array}{l}\text { To give the } \\
\text { national } \\
\text { consciousness. }\end{array}$ & $\begin{array}{c}7 \\
3.6\end{array}$ \\
\hline & & $\begin{array}{l}\text { He is the founder of } \\
\text { our country. }\end{array}$ & $\begin{array}{c}22 \\
11.5\end{array}$ & $\begin{array}{c}\text { To give the } \\
\text { country } \\
\text { (homeland) love }\end{array}$ & $\begin{array}{c}6 \\
3.1\end{array}$ \\
\hline & & $\begin{array}{c}\text { He saved the } \\
\text { homeland from } \\
\text { enemy occupation. }\end{array}$ & $\begin{array}{c}21 \\
11.0\end{array}$ & $\begin{array}{l}\text { He gave direction } \\
\text { to Turkish history. }\end{array}$ & $\begin{array}{c}5 \\
2.6\end{array}$ \\
\hline & & $\begin{array}{l}\text { It should be taught } \\
\text { what he did for the } \\
\text { sake of homeland. }\end{array}$ & $\begin{array}{c}20 \\
10.5\end{array}$ & $\begin{array}{l}\text { He has enabled us } \\
\text { to national unity. }\end{array}$ & $\begin{array}{c}5 \\
2.6\end{array}$ \\
\hline & & $\begin{array}{l}\text { He has brought } \\
\text { democracy to the } \\
\text { country and } \\
\text { modernized it. }\end{array}$ & $\begin{array}{l}17 \\
8.9\end{array}$ & $\begin{array}{l}\text { He has changed } \\
\text { the future of the } \\
\text { country. }\end{array}$ & $\begin{array}{c}3 \\
1.5\end{array}$ \\
\hline & & $\begin{array}{l}\text { The most } \\
\text { appropriate lesson } \\
\text { is Social Studies. }\end{array}$ & $\begin{array}{l}15 \\
7.8\end{array}$ & $\begin{array}{c}\text { Every nation } \\
\text { needs heroes to } \\
\text { teach the children. }\end{array}$ & $\begin{array}{c}3 \\
1.5\end{array}$ \\
\hline & & $\begin{array}{l}\text { Students should } \\
\text { know the national } \\
\text { history and heroes. }\end{array}$ & $\begin{array}{r}14 \\
7.3\end{array}$ & $\begin{array}{l}\text { He has created a } \\
\text { free society. }\end{array}$ & $\begin{array}{c}2 \\
1.0\end{array}$ \\
\hline & & $\begin{array}{l}\text { He was of help to } \\
\text { his people. }\end{array}$ & $\begin{array}{c}9 \\
4.7 \\
\end{array}$ & $\begin{array}{l}\text { He is a genius } \\
\text { commander. }\end{array}$ & $\begin{array}{c}2 \\
1.0 \\
\end{array}$ \\
\hline \multirow[t]{2}{*}{ No } & \multirow[t]{2}{*}{$\begin{array}{c}15 \\
10.6\end{array}$} & $\begin{array}{l}\text { He is holding } \\
\text { unduly much space } \\
\text { in the program. }\end{array}$ & $\begin{array}{c}5 \\
2.6\end{array}$ & \begin{tabular}{|l} 
Turkish History \\
should be \\
reviewed to \\
reconsider. \\
\end{tabular} & $\begin{array}{c}2 \\
1.0\end{array}$ \\
\hline & & $\begin{array}{l}\text { He should not be } \\
\text { given to students in } \\
\text { the form of } \\
\text { imposition. }\end{array}$ & $\begin{array}{c}3 \\
1.5\end{array}$ & $\begin{array}{c}\text { Values can be } \\
\text { taught by the other } \\
\text { heroes. }\end{array}$ & $\begin{array}{c}1 \\
0.5\end{array}$ \\
\hline
\end{tabular}




\section{International Journal of Science and Research (IJSR) \\ ISSN (Online): 2319-7064}

Index Copernicus Value (2013): 6.14 | Impact Factor (2015): 6.391

\begin{tabular}{|l|l|c|c|c|c|}
\hline & $\begin{array}{c}\text { We can not say } \\
\text { everything was } \\
\text { good that Ataturk } \\
\text { did. }\end{array}$ & $\begin{array}{c}2 \\
1.0\end{array}$ & $\begin{array}{c}\text { Social Studies } \\
\text { should reflect the } \\
\text { daily life. }\end{array}$ & 0.5 \\
\hline
\end{tabular}

The questions directed to the social studies teacher candidates "Should we teach Ataturk in social studies as a historical hero? Why?" the given answers and reasons are screened on Table 3. Because a student give different answers in the same theme or different themes, (f) the number (n) numbers have varied. According to this chart, majority of teacher candidates within this work group claimed: yes Ataturk should be in social studies curriculum by $\% 89.4$ and only a minor group claimed: no, it is unnecessary by $\% 10.6$. Both groups give different reasons for their answers. The group with positive approach $(\% 13.1)$ reasoned their answers saying that "Ataturk is good rolemodel". The group with negative approach $(\% 2.6)$ reasoned their answers saying that "Ataturk takes unnecessarily too much space on the curriculums".

\section{Conclusion}

Looking at the quantitative results of the study, Social Studies teacher candidates in the study group have high perception about Ataturk. According to them, Ataturk is an ideal person that should be taught to students. According to $\mathrm{t}$-Test results, there was not statistically significant difference according to gender about the perception of Ataturk. In other words, both female and male participants have similarly high Ataturk perception.

Considering of Social Studies teacher candidates' views about teaching of Ataturk as a historical hero in Social Studies lesson, it is seen that the majority of participants who will teach Social Studies has declared that Ataturk should be taught in the lesson. In other words, most of the teacher candidates prefer Ataturk to remain in program. Looking at the reasons, they think that he has a personality to be an example for the children. Participants regard Ataturk as the savior and founder of the country. They also see that Social Studies is the most appropriate course to teach Ataturk. As mentioned in the introduction of research, the study group has expressed that the student should recognize their national heroes and according to them Ataturk is an ideal hero for this.

In light of results of obtained data from the study that can be made the following recommendations: Mustafa Kemal Ataturk can be taught using different methods and techniques at every grade level of social studies lesson. In this way, students acquire historical information on the one hand, recognize the one that may constitute a role model for them on the other side. This study attempted to describe the study group's opinions about teaching Ataturk as a historical hero in the course, as well as similar studies can be done for different historical hero in Turkey and World History.

\section{References}

[1] Altıkulaç, A. (2008). 8. Sınıf T.C. İnkılâp Tarihi ve Atatürkçülük Dersinde Bir Öğretim Tekniği Olarak
"Drama". Yayınlanmamıș Yüksek Lisans Tezi. Gazi Üniversitesi. Eğitim Bilimleri Enstitüsü. Ankara.

[2] Aslan, A. (1991). Sömürülen Atatürk ve Atatürkçülük. 10. Baskı. Ankara: Şafak Matbaacılık.

[3] Balswick, J. (1982). Heroes and Heroines Among American Adolescents. Sex Roles, Vol 8, No. 3, pp. 243249.

[4] Brodbelt, S., Wall, R. E. (1985). An Examination of the Presentation of Heroes and Heroinesin Current (1974-1984) Secondary Level Social Studies Textbooks.

[5] Dönmez, C., Hamarat, E. (2014). Atatürk Algııı Ölçeğinin Geliştirilmesi: Geçerlik ve Güvenirlik Çalışması, İlköğretim Online, 13(3), pp. 820-826.

[6] Erendil, M. (1986). Çok Yönlü Lider Atatürk. Genelkurmay Askeri Tarih ve Stratejik Etüt Başkanlığı Yayınları. Ankara: Genelkurmay Basımevi.

[7] Gnkur. Başk. (1982). Atatürkçülük: Atatürk'ün Görüş ve Direktifleri. Ankara: Genelkurmay Basımevi.

[8] Giritli, İ. (1995). "Atatürkçü Düşünce, Atatürk İlke ve İnkılapları”, Atatürkçü Düşünce El Kitabı. Ankara: Atatürk Araştırma Merkezi.

[9] Karasar, N. (1999) Bilimsel Araştırma Yöntemi, Ankara: Nobel Yayınevi.

[10] Koca, H. (2005). İlk ve Orta Öğretimde Atatürk İlke ve İnkılaplarının Öğretimi. İlk ve Orta Öğretim Okullarında Türkiye Cumhuriyeti İnkılap Tarihi ve Atatürkçülük Konularının Öğretimi: Mevcut Dirim, Sorunlar ve Çözüm Önerileri (Ed. M. Saray, H. Tosun). Ankara: Atatürk Araştırma Merkezi.

[11] MEB, (2005). İlköğretim Sosyal Bilgiler Dersi (4-5. Sınıflar) Öğretim Programı. Ankara: Talim Terbiye Kurulu Başkanlığı.

[12] MEB, (2005). İlköğretim Sosyal Bilgiler Dersi (6-7. Sınıflar) Öğretim Programı. Ankara: Talim Terbiye Kurulu Başkanlığı.

[13] Miles, M. B. and Huberman, A. M. (1994). Qualitative data analysis : An expanded sourcebook. (Second Edition). Thousand Oaks, California: SAGE Publications, Inc.

[14] Oğuz, İ.,İra, N., Oğuz, Ş., Tekin, S. (2005). Atatürkçülük Konularının Hayat Bilgisi ve Sosyal Bilgiler Derslerinde Aktif Öğrenme Yöntemleriyle İşlenişi. İlk ve Orta Öğretim Okullarında Türkiye Cumhuriyeti İnkılap Tarihi ve Atatürkçülük Konularının Öğretimi: Mevcut Dirim, Sorunlar ve Çözüm Önerileri (Ed. M. Saray, H. Tosun). Ankara: Atatürk Araştırma Merkezi.

[15] Sağlam, M. (1988). Atatürkçülük ve İnkılap Metodolojisi. Atatürk'e Armağan. Yay. Haz. M. Sağlam, B. Kodaman, M. Özbalcı. Samsun: Ondokuz Mayıs Üniversitesi.

[16] Staats, S., Hupp, J. M., \& Hagley, A. M. (2008). Honesty and Heroes: A Positive Psychology View of Heroism and Academic Honesty. The Journal of Psychology, 2008, 142(4), pp. 357-372.

[17] Warren, R. P. 1972. A dearth of heroes. American Heritage. 23(6): pp. 4-7, 95-99.

[18] Yazıcı, K., (2009). Sosyal Bilgilerde Atatürkçülük Konularının Öğretimi. Sosyal Bilgiler Öğretimi (Ed. M. Safran). Ankara: Pegem Akademi.

[19] Yazıc1, S., Aslan, M. (2011). Değerler Eğitiminde Kahramanlardan Yararlanma: Sosyal Bilgiler Ders Kitapları ile Öğretmen Adaylarının Kahraman Tercihlerinin Karşılaştırılması Üzerine Bir Çalışma. Kuram ve Uygulamada Eğitim Bilimleri, 11 (49), pp. 2173-2188.

[20] Yazıcı, K., Koca, K. (2008). Sosyal Bilgiler Öğretim Programı. Özel Öğretim Yöntemleriyle Sosyal Bilgiler Öğretimi. (Ed. B. Tay, A. Öcal). Ankara: Pegem Akademi. 